\title{
Improving Students' Academic Achievements in Secondary Schools Economics Classes: The Role of Demographic Characteristics and Teachers' Knowledge
}

\author{
Nubonyin Hilda Fokong \\ Department of Curriculum and Pedagogy, Faculty of Education, The University of Bamenda, Cameroon \\ P.O.Box 39 Bambili-Cameroon
}

\begin{abstract}
One of the most important aspects in the teaching learning process that can be controlled by the classroom teacher is the quality of instruction. This study aimed at examining the extent to which teachers' and students' characteristics as well as teachers' pedagogic content knowledge boost students' academic achievement. The study was carried out at seven (07) economics classes in Cameroonian secondary schools. The survey research design was applied in the study. A total of four hundred and forty four (444) secondary school students and thirty three (33) teachers from the North West Region participated in this study. Questionnaires were used for data collection. Data were analyzed using descriptive statistical technique. The findings reveal that to a greater extent teachers' and students' characteristics as well as teachers' pedagogic content knowledge enhance students' academic achievement in economics classes in Mezam Division. This study therefore puts forward a policy approach called valuable teaching and learning (for teachers and students) for improving on knowledge, competence and attitudes towards economics.
\end{abstract}

Keywords: Students' academic achievements, teachers' characteristics, students' characteristics, teachers' pedagogic content knowledge, Cameroon

DOI: $10.7176 / \mathrm{JEP} / 11-32-14$

Publication date: November $30^{\text {th }} 2020$

\section{Introduction}

Notable in the education domain, Mezam Division has one state university located in Bambili with several secondary, primary and nursery schools. In order to facilitate management and improve students' academic achievement in Mezam Division, the educational sector is organized according to two delegations namely: delegation of basic education and secondary education. These delegations are located in Bamenda, the headquarters of the North West Region. There are 46 public secondary general education schools (SGES) in Mezam Division out of a total of 252 (18.3\%) government SGES in the North West Region (Munda, 2017).

At the start of the 2016/2017 academic year, secondary general education schools in Mezam Division had a total population of 19,475 students out of a total of $80,000(24.3 \%)$ students of both secondary general and technical education schools found in the North West Region. It is worthy to note that, at the end of the 2016/2017 academic year the North West had a total population of 58, 000 students with 24,000 (41.4\%) of these students population found in Mezam Division (Regional Delegation of Secondary Education North West (RDSENW) and Divisional Delegation of Secondary Education Mezam (DDSEM), 2016/2017 Academic Year). At the start of the 2016/2017 academic year government secondary general education schools in Mezam Division had a total population of $107(42.8 \%)$ teachers of economics out of a total of 250 teachers of economics found in government secondary general education schools in the North West Region (RDSENW and DDSEM, 2016/2017 Academic Year). The enrolment statistics of students at the start of 2016/2017 academic year in Mezam Division indicates that, there are more females (61.0\%) as opposed to males (39.0\%) in schools (RDSENW and DDSEM, 2016/2017 Academic Year). Similarly, enrolment statistics of teachers at the start of 2016/2017 academic year in Mezam Division indicates that, there are more females (57.9\%) as opposed to males $(42.1 \%)$ in schools (RDSENW and DDSEM, 2016/2017 Academic Year).

Munda (2017) emphasized that contrary to public opinion that Mezam Division is overcrowded with human resources such as teachers, it is worthy to note that this division still experiences shortage of economics teachers in some schools. To the divisional delegate this situation is further compounded by the general deficiency in infrastructure and equipment in all government secondary schools. He reiterated that these schools express the need for infrastructures like classrooms, specialised rooms like multimedia centres, libraries as well as equipment like computers, printers and photocopiers (Munda, 2017).

Notwithstanding these human and material challenges, some economics authors have indicated that, teachers, particularly at the secondary school level, are required to be knowledgeable and competent to guide their students to perform well on standardized examination and to prepare them for higher learning (Nkom 2008; Wemnje, 2013; Akuro, 2015; Samjela and Voma, 2015; Alobwede, 2015). Interestingly, some research in economics has showed that meaningful learning hardly takes place in economics classroom. For example, addressing the teachers of 
economics pedagogical content knowledge during a seminar that focused on practical teaching in economics for improved performance, the regional pedagogic inspector (RPI), Mr. Simon Kiyong $\left(29^{\text {th }}\right.$ Novermber, 2015) said teachers of economics knowledge of the scope in economics is shallow. This is because their examples are mostly textbook examples only consequently, they lack the application exercises to buttress concepts. He argued that this situation is further compounded because teachers teach with no teaching aids like charts or real objects. Teachers do not show mastery of lesson and subject content by using subject jagons like change in supply, change in quantity supplied, and so on (Kiyong, 2015).

In keeping with this view, a seminar of the North West Economics Teacher's Association (NOWETA, 2015) acknowledges that the mastery learning policy (Tambo, 2003) is hardly implemented by teachers of economics. For example, the RPIs have observed that teachers of economics do much of the talking and the students take notes and listen. These teachers avoid calculations and graphs in their teaching and even those who do them provide brief explanations and they do so with stress. To many teachers formative evaluation is waste of time and so they teach with no questions. These teachers hardly give assignments and when they give they are hardly corrected (NOWETA, 2015). Based on these explanations Samjela and Voma (2015) observed that students' poor achievement in economics and the difficulties that students face in integrating the subject matter in Ordinary Level $(\mathrm{O} / \mathrm{L})$ and Advanced Level $(\mathrm{A} / \mathrm{L})$ economics is cause by teachers' inability to sequence the subject matter in micro and macroeconomics at the $\mathrm{O} / \mathrm{L}$.

The foregoing therefore shows that, the role of demographic characteristics and teachers' knowledge in improving students' academic achievement in secondary schools economics classes is doubtful. This study attempts to examine the following objectives; 1) to determine the extent to which teachers' demographic characteristics improve students'academic achievement in secondary schools economics classes at the ordinary level, 2) to analyze the extent to which students' demographic characteristics improve students' academic achievement in secondary schools economics classes at the ordinary level, 3) to investigate the extent to which teachers' pedagogical content knowledge improve students'academic achievement in secondary schools economics classes at the ordinary level, 4) to identify the types of formative assessment test used by economics teachers in secondary schools economics classes at the ordinary level, 5) to identify factors that can improve students' academic achievement in secondary schools economics classes at the ordinary level.

\section{Review of Related Literature}

Employing Pedagogical Content Knowledge (PCK) theory of Shulman (1987), Kola and Sunday (2015) lays emphasis on the fact that, PCK embodied a unique form of teacher professional knowledge. According to them, PCK is specifically for professional teachers because it guides the teachers' actions when dealing with the subject matter in the classroom. They further stated that, teachers' PCK is the knowledge that teachers develop over time, and through experience, about how to teach a particular content in particular ways to enhance student understanding and their academic achievement. PCK therefore refers to a teacher's possession and creative usage of subject content knowledge, general pedagogical knowledge, and the knowledge of educational contexts and goals to deal with ever changing classroom situation (Shulman, 1987).

Following the Cognitive Constructivism Theory of Piaget (1970), Ntoh (2015) reports that in order to enhance students' achievement in economics, the complex activity of teaching in economics must focus on promoting active learning via cognitive engagement, building on pre-existing knowledge, encouraging learning to take place in a social context and using the learner centred model.

In Kirinyaga country, Luketero and Kangangi (2019) sampled 34 secondary schools, 68 heads of department and 34 deans of studies to examine the factors influencing students' academic performance in Kenya certificate of secondary education. They used three sets of questionnaires to collect data for the study. The correlation results revealed that school resources, teacher student ratio, peer influence, the use of drugs, pre-marital sex, indecent dressing and motivation had severe influence on students' academic performance. In an earlier study in Kenya, Jepketer, Kombo and Kyalo (2015) sampled 30 public secondary schools, 30 school principals, 85 teachers and 136 students and attributed students poor performance to insufficient funding for facilitating educational activities and low student entry behaviour. The results further showed that seminars, workshops and conferences assist teachers' acquire extra teaching skills in their subject areas to enhance students' performance.

In Nigeria, Amalu and Dasel (2019) conducted a study on academic locus of control, study habits and secondary school students' academic achievement in mathematics. The results revealed that there are significant relationship between internal locus of control and good study habits on secondary school students' academic achievement in mathematics.

Olufemi, Adediran and Oyediran (2018) used a survey research design and a sample of 480 students from 6 colleges of education to assess factors affecting students' academic performance in colleges of education in Nigeria. Data collected through the use of well structured interview guide and class observation were analysed with descriptive and inferential statistics. Their findings indicated that parents' socio- economic background, students, teachers and school factors had serious influence on students' academic performance. These findings are in 
consonance with the findings of Kapur (2018) who maintained that, parents' characteristics, poverty, school resources, attitude of students, classroom environment, class size, skills and abilities of teachers had enormous influence on students' academic performance in India.

Arshad and Akramnaseem (2013) used questionnaires and a sample of 150 teachers and 300 students in Pakistan to indicate that, trained teachers are found more effective in their performance than untrained teachers in improving students learning. Similarly, Walstad and Watts (2015) findings conclude that, teacher education in economics is essential for improving student learning in the subject.

Using a sample of 11 teachers from America, Falk (2012) descriptive findings reveal that teachers most frequently made use of their existing knowledge of instructional strategies and curriculum. In Greece, Liakopoulou (2011) used questionnaires administered to 727 teachers and descriptive statistics to reveal that knowledge acquisition on the subject taught and pedagogy are necessary tools for effective teaching.

In a survey, Schug, Dieterle, and Clark (2009) analyzed data collected from 300 economics teachers and 901 other social studies teachers to explain that economics teachers are somewhat more activity oriented than other social studies teachers. In relation to this Ballard and Bates (2008) descriptive findings indicate that some factors that contributed to student's performance were student's attitude towards the tests, school or study habits, student's home life or parental involvement, student's health on the day of the test and teachers providing quality classroom instruction to their students. These findings were in agreement with those of Mishra and Koehler (2006) and Black and William (1998) that teachers' PCK enhance students' achievement positively.

In America, Howard, Hodgin and Zietz (2003) used a regression technique on 3,322 observations with information compiled from faculty questionnaires, student questionnaires, and student test scores along with the student evaluations of teaching to argue that teachers' knowledge of pedagogy matters when measuring students' achievement in economics. These results confirm Darling-Hammond (2000) regression results that, it is the expertise of the teachers (measured by academic ability, years of education, years of teaching experience, subject matter and teaching knowledge, certification status, and teaching behaviours in the classroom) that make learning occur for students.

\section{Methodology}

The study was conducted in Mezam Division, North West Region of Cameroon. The study employed a survey research design. The study used purposive sampling technique to select the teachers and students of economics; stratified as well as simple random sampling techniques to select the public secondary general education schools and classes, as well as proportional sampling techniques to select students of economics. Specifically, 20\% of students from each school were selected regardless of the size of the subdivision. According to Krejcie and Morgan (1970) as cited in Amin (2015), when a population size is above 2,200, 95\% confidence level and sampling error of $5 \%$ the sample size is set at 327 and more. Based on the above information, the study employed 444 students out of a target of 2,220 and 33 teachers out of a population of 33. The study sampled 7 public secondary general education schools in Mezam Division from a total population of 46.

Students' academic achievement was measured using regional mock examination. This is in line with the opinions of Black and William, (1998). Demographic characteristics were measured using qualification, longevity, work status and age (Darling-Hammond, 2000). Teachers' PCK was measured using teachers' content knowledge, pedagogical knowledge, knowledge of educational contexts and goals to deal with ever changing classroom situation (Shulman, 1987). Two sets of questionnaires were used to collect data for the study. Validations of the instrument were done in consultation with research experts in the department of Curriculum and Pedagogy. The reliability test for the instrument was conducted using test retest method. Questionnaires were administered to the students and teachers on a face to face basis. Data collected were analysed using descriptive statistics. Count or frequencies and percentages were used to describe the responses registered. Presentation of data was done using frequency tables. All ethical issues were considered. 
4. Presentation of Findings

Table 1a: Demographic Characteristics of Teachers

\begin{tabular}{|c|c|c|c|c|c|c|c|c|c|c|}
\hline $\begin{array}{l}\text { Name of } \\
\text { Subdivision/school }\end{array}$ & \multicolumn{5}{|c|}{ Qualification of Teachers } & \multicolumn{5}{|c|}{$\begin{array}{l}\text { Longevity as Teacher } \\
\text { (measured in years) }\end{array}$} \\
\hline & MA/Msc & BA/Bsc & $\begin{array}{l}\text { DIPES } \\
\text { II }\end{array}$ & $\begin{array}{l}\text { DIPES } \\
\text { I }\end{array}$ & TOTAL & $\begin{array}{l}0- \\
5\end{array}$ & $\begin{array}{l}6- \\
10\end{array}$ & $\begin{array}{l}11- \\
15\end{array}$ & $16+$ & TOTAL \\
\hline $\begin{array}{l}\text { Bamenda I } \\
\text { GBHS }\end{array}$ & & & & & & & & & & \\
\hline $\begin{array}{l}\text { Bamendankwe } \\
\text { Bamenda II }\end{array}$ & 1 & 1 & 1 & 1 & 4 & 0 & 2 & 0 & 2 & 4 \\
\hline GBHS Bamenda & 0 & 0 & 6 & 0 & 6 & 1 & 3 & 2 & 0 & 6 \\
\hline $\begin{array}{l}\text { GBHS Down Town } \\
\text { Bamenda III }\end{array}$ & 2 & 1 & 2 & 0 & 5 & 1 & 3 & 0 & 1 & 5 \\
\hline GBHS Atiela & 0 & 1 & 0 & 3 & 4 & 0 & 0 & 0 & 4 & 4 \\
\hline $\begin{array}{l}\text { GBHS Bayelle } \\
\text { Santa }\end{array}$ & 0 & 0 & 1 & 2 & 3 & 1 & 0 & 1 & 1 & 3 \\
\hline $\begin{array}{l}\text { GHS Akum } \\
\text { Tubah }\end{array}$ & 0 & 1 & 3 & 1 & 5 & 1 & 0 & 1 & 3 & 5 \\
\hline CCAST Bambili & 0 & 3 & 3 & 0 & 6 & 0 & 0 & 0 & 6 & 6 \\
\hline Sample Total & 3 & 7 & 16 & 7 & 33 & 4 & 8 & 4 & 17 & 33 \\
\hline
\end{tabular}

Key: M.A. = Master of Arts; M.Sc. = Master of Science; B.A. = Bachelor of Arts; B.Sc. = Bachelor of Science; DIPES I= Secondary School Teacher Diploma I; DIPES II = Secondary School Teacher Diploma II

Source: Computed by Researcher using School Statistics

Table 1a indicates that 21.2\% (7) of teachers are holders of DIPES I or B.A. /B.Sc. as opposed to 9.1\% (9) of teachers who are holders of M.A. /M.Sc. however, a vast majority (48.5\% or 16) of these teachers had DIPES II. Thus, the sample was dominated by holders of DIPES II. This implies that the teachers from this sample possess knowledge of subject matter and methods. In other words, the total sample population of teachers were generally considered well qualified for teaching the subject economics within public secondary general education schools in Mezam Division.

Table 1b: Demographic Characteristics of Teachers

\begin{tabular}{|l|l|l|}
\hline Work Status & Frequency & Percentage \\
Chief Examiner & 2 & 6.1 \\
Examiner & 7 & 21.2 \\
Assistant Examiner & 11 & 33.3 \\
Teacher & 13 & 39.4 \\
\hline
\end{tabular}

Source: Researcher's calculation based on data from teachers' questionnaire

With regards to work status, table $1 \mathrm{~b}$ indicates that $39.4 \%$ of respondents never participated in the scoring or grading of General Certificate of Education (GCE) examination. Furthermore, $33.3 \%$ of teachers were assistant examiners, $21.2 \%$ of the respondents were teachers and examiners, and $6.1 \%$ of respondents were both teachers and chief examiners. Thus, the sample was dominated by respondents that had already participated in the planning, administration, scoring and/or grading of GCE examination. This indicates that the respondents from this sample had knowledge of formative assessment.

Table 2: Demographic Characteristics of Students

\begin{tabular}{|l|l|l|}
\hline Age Group & Frequency & Percentage \\
$11-13$ & 4 & 0.9 \\
$14-16$ & 293 & 66.0 \\
$17-19$ & 133 & 30.0 \\
$>20$ & 14 & 3.2 \\
Longevity as an economics student in form five & & \\
1 year & & \\
2 years & 307 & 69.1 \\
3 years & 65 & 14.6 \\
4years + & 34 & 7.7 \\
& 38 & 8.6 \\
\hline
\end{tabular}

Source: Researcher's calculation based on data from students' questionnaire

Table 2 shows that majority of the respondents $(66.0 \%)$ were between the ages of $14-16$ years, followed by those between the ages of $17-19$ years, then those with 20 years and above. Only $0.9 \%$ of respondents fell between the age group of $11-13$ years. This implies that a majority of respondents were mentally ready to understand the concepts taught in economics. A large majority of respondents in form five $(69.1 \%)$ had attended economics 
classes for three years (that is, from form 3 to 5 ) and had participated in the regional mock examination once (that is, in form 5). Furthermore, $14.6 \%$ of respondents had attended economics classes for 4 years and had been students in form five for two years. This implies that, this category of respondents had participated twice in the regional mock and once in the GCE examination. Moreover, 7.7\% and $8.6 \%$ of respondents had attended economics classes for 5 years and above. They had participated both in the regional mock and GCE examinations repeatedly. Therefore, the demographic characteristics of students indicate that all the respondents have been taught economics for a relatively long time. Thus, they have a good knowledge of their teachers and can assess their teachers' pedagogically content knowledge of economics.

Table 3: Teachers' Pedagogical Content Knowledge and Students' Achievement

\begin{tabular}{|l|cc|cc|}
\hline \multicolumn{1}{|c|}{ QUESTION } & \multicolumn{2}{c|}{ STUDENTS } & \multicolumn{2}{c|}{ TEACHERS } \\
\hline $\begin{array}{l}\text { Does the teachers' PCK account for students' } \\
\text { achievement in economics }\end{array}$ & Frequency & Percentage & Frequency & Percentage \\
\hline Yes & 314 & 70.7 & 33 & 100 \\
No & 130 & 29.3 & 0 & 0 \\
Total & 444 & 100 & 33 & 100 \\
\hline
\end{tabular}

Source: Researcher's calculation based on data from students and teachers

Table 3 reveals that, a large majority of students 314 (70.7\%) and teachers $33(100 \%)$ agreed that the teachers' PCK accounts for students' achievement in economics while $130(29.3 \%)$ of the students' disagreed that the teachers' PCK accounts for students' achievement in economics.

Table 4: Description of Responses with Regards to how the Teachers' Pedagogical Content Knowledge Accounts for Students' Academic Achievement

\begin{tabular}{|c|c|c|}
\hline SN & $\begin{array}{l}\text { Factors advanced for how teachers' pedagogical content knowledge accounts } \\
\text { for students' achievement }\end{array}$ & $\begin{array}{l}\text { Frequency } \\
\text { Percentage }\end{array}$ \\
\hline 1. & Good use of teaching methods/ techniques & 23.2 \\
\hline 2. & Good explanation of the subject matter in economics. & 21.0 \\
\hline 3. & Good lesson preparation & 20.0 \\
\hline 4. & Constant assessment of student with the use of assignment. & 16.2 \\
\hline 5. & Regular seminar attendance by teachers. & 14.0 \\
\hline 6. & Good understanding of students' prior knowledge, understanding and difficulties. & 5.6 \\
\hline
\end{tabular}

Source: Researcher's calculation based on data from students and teachers

Findings from table 4 were in line with the three knowledge domains of pedagogical content knowledge. In general, a large majority of respondents $116(23.2 \%)$ indicated that teachers had knowledge of teaching methods / techniques; $105(21.0 \%)$ of the respondents specified that teachers knowledge of content accounted for students' achievement; $100(20.0 \%)$ noted that good knowledge of lesson preparation by teachers enhance students' achievement. Moreover, $81(16.2 \%)$ of the respondents pointed out that teachers' knowledge of formative assessment like using assignments to assess students' accounts for students' achievement and 70(14.0\%) of the respondents agreed that teachers attended seminars regularly. A weak majority of respondents 28(5.6\%) highlighted that teachers' knowledge of students' prior knowledge, understanding and difficulties also accounts for students' achievements in economics. It is worth noting that, while $314(70.7 \%)$ respondents agreed that teachers' pedagogical content knowledge accounts for their achievement in economics, 130 (29.3\%) respondents disagreed. Thus, the sample was dominated by respondents that agreed.

Table 5: Teachers' Knowledge of Types of Formative Assessment

\begin{tabular}{|c|l|ll|}
\hline SN & Teachers' knowledge and use of Types of Formative Assessment & Frequency & Percentage \\
\hline 1 & Oral exchange of questions and answers & 223 & 50.2 \\
2 & Essay questions (written test) & 101 & 22.7 \\
3 & Multiple choice type of questions(written test) & 70 & 15.8 \\
4 & Structural type of questions (written test) & 29 & 6.5 \\
5 & Problem solving questions (written test) & 7 & 3.2 \\
6 & Questions demanding the plotting of graphs (written test) & & 1.6 \\
\hline
\end{tabular}

Source: Researcher's calculation based on data from students and teachers

Findings on table 5 revealed that a large majority of respondents $223(50.2 \%)$ indicated oral assessment as the popular formative assessment type used by teachers; $101(22.7 \%)$ specified that their teachers used essay questions; $70(15.8 \%)$ noted that their teachers used multiple choice questions; few respondents $29(6.5 \%)$ and $14(3.2 \%)$ listed structural and problem solving questions as formative assessment types used by their teachers. The least formative assessment type is the use of questions that demand the plotting of graphs which registered a frequency of $7(1.6 \%)$. 
Table 6: Description of Responses with Regards to the Factors Accounting for Students'Academic Achievement

\begin{tabular}{|c|l|ll|}
\hline SN & Factors advanced for students' Achievement & Frequency & Percentage \\
\hline 1. & Good explanation of the subject matter in economics. & 85 & 16.0 \\
2. & Hard work by both teachers and students. & 70 & 13.3 \\
3. & Good teaching methods. & 60 & 11.3 \\
4. & Regular school attendance by students. & 55 & 10.4 \\
5. & Class discipline. & 50 & 9.4 \\
6. & Regular revision of past GCE questions with students. & 45 & 8.5 \\
7. & Possession of textbooks by students. & 40 & 7.5 \\
8. & Poor explanation of content & 35 & 6.6 \\
9. & Good lesson preparation & 30 & 5.7 \\
10. & Much devotion from teachers to cover syllabus. & 25 & 4.7 \\
11. & Regular class counselling by teachers and follow up. & 20 & 3.8 \\
12. & Non commitment on the part of students/ teachers. & 15 & 2.8 \\
\hline
\end{tabular}

Source: Researcher's calculation based on data from students and teacher

Table 6 shows the factors which respondents had indicated as either positive or negative contributors to students' achievement in economics. They were varied, but for analysis purpose they are classified into 12 categories. A large majority of respondents $85(16.0 \%)$ indicated good explanation of the subject matter; $70(13.3 \%)$ indicated hard work by both teachers and students; 60 (11.3\%) noted good teaching method; 55(10.4\%) indicated regular school attainment by students, 50(9.4\%) noted class discipline, few respondents $45(8.5 \%)$ listed regular revision of past GCE questions with students, 40(7.5\%) indicated the possession of textbooks by students and 35 $(6.6 \%)$ highlighted poor explanation of content. The least factor is non-commitment on the part of students/ teachers which registered a frequency of $15(2.8 \%)$.

Table 7: Proposals to Enhance and Improve on Students'Academic Achievement in Economics

\begin{tabular}{|c|l|cc|}
\hline SN & \multicolumn{1}{|c|}{ Proposals } & Frequency & Percentage \\
\hline 1. & Presentation of content sequentially and correctly & 210 & 21.6 \\
2. & Constantly give students assignment & 177 & 18.2 \\
3. & Teach by applying concepts to real life situations & 130 & 13.4 \\
4. & Encourage students to buy an read textbooks & 110 & 11.3 \\
5. & Proper use of appropriate teaching methods & 80 & 8.2 \\
6. & Proper explanation of rationale of the topic to students & 70 & 7.2 \\
7. & Provide immediate and correct feedback to students & 63 & 6.5 \\
8. & Encourage revision and solving of past GCE questions with students & 57 & 5.7 \\
9. & Motivate and counsel students regularly & 42 & 4.2 \\
10. & Attending seminars and departmental meetings regularly & 33 & 3.4 \\
\hline
\end{tabular}

\section{Source: Researcher's calculation based on data from students and teachers}

Table 7 shows the proposals put forth by respondents to enhance and improve on students' achievement in economics. These proposals were prioritised. The salient factors include: presentation of content sequentially and correctly (21.6\%), giving students assignment regularly (18.2\%), applying concepts to real life situations (13.4\%), encouraging students to buy and read textbooks (11.3\%), proper use of appropriate teaching methods $(8.2 \%)$, proper explanation of rationale of the topic to students $(7.2 \%)$, providing immediate and correct feedback to students (6.5\%), encouraging revision and solving of past GCE questions with students (5.7\%), motivating and counselling students regularly (4.2\%) as well as attending seminars and departmental meetings regularly (3.4\%).

\section{Discussion of Findings}

Generally, from the analysis of the questionnaires that scrutinized teachers' pedagogical content knowledge (PCK) of economics and its effects on students' achievement it was clearly seen that, both students and teachers overwhelmingly agreed that there is an effect of teachers' pedagogical content knowledge on form five students' examination scores in economics. This positive effect can be attributed to the fact that, teachers attended seminars regularly and had knowledge of teaching methods/techniques; content; lesson preparation; formative assessment types (like using assignments to assess students' learning) as well as they had knowledge of students' prior knowledge, understanding and difficulties. These findings are therefore in consonance with the position of Shulman's (1987) that teachers' knowledge of subject matter, teaching methods/strategies and learners' conceptions have a great influence on students' academic achievement.

Furthermore, the findings showed that students' achievements at examinations were to a greater extent influenced by teachers' knowledge of micro economics and macroeconomics content. This can be ascribed to the fact that the teachers were holders of M.A. /M.Sc., B.A. /B.Sc., DIPES II and DIPES I. This implies that, they were generally well trained for teaching the subject (economics) within public secondary school in Mezam Division. Similarly, Arshad and Akramnaseem (2013) reiterated that, subject knowledge between untrained and 
trained teachers has contributed significantly to students' achievement. They had observed that, $74 \%$ students' of untrained teachers were found satisfied with their teachers' content knowledge whereas, $85 \%$ students of trained teachers were found satisfied with their teachers' content knowledge. Thus, they concluded that, trained teachers were found to be more effective in their performance than untrained teachers. On this interpretation Walstad and Watts (2015) reached completely the same conclusion as Arshad and Akramnaseem (2013) that, teacher education in economics is essential for improving student learning in the subject.

Moreover, looking at the factors that account for students' achievement in economics, both students and teachers attested that teachers' pedagogical content knowledge had either a positive or negative effect on form five students' examination scores in economics. To a larger extent the respondents had indicated that teachers' knowledge of subject matter was the most salient contributor to students' achievement in economics, followed by the teachers' knowledge of teaching method, teachers' knowledge of classroom management while teachers' knowledge of formative assessment and teachers' knowledge of students' conceptions were the least effective factors. In addition to teachers' PCK, other factors that the respondents had specified as positive contributors to students' achievement in economics were hard work by both teachers and students; regular school attendance by students; possession of textbooks by students and syllabus coverage. The proposed solutions are congruent with Piaget's (1970) theory on onstructivism. The findings reaffirm Luketero and Kangangi (2019) as well as Ntoh's (2015) arguments. Definitely, it can be said that teachers' knowledge of content and utilization of different types of active methods to teach this content to learners enhance their learning of this content.

On the one hand, the findings showed that, teachers' knowledge of suitable teaching methods has a positive influence on students' achievement in economics. This can be attributed to the fact that most of the teachers usually attended seminars and fell within the group range of 16 years and above of subject teaching experience. The findings were also in line with those of Jepketer, Kombo and Kyalo (2015) who found that seminars, workshops and conferences assisted teachers' to acquire extra teaching skills in their subject areas and to change their attitudes. Jepketer, et al. (2015) concluded that majority of the teachers were qualified and well trained. They were equipped with necessary skills, knowledge and competencies in their subject areas consequently; they articulated their teaching areas and enabled students to perform better.

On the other hand, findings have also shown a consistent effect of teachers' knowledge of adapting teaching methods and content to the needs of their students. However, most teachers do not adapt their teaching methods and content to the needs of their students. Specifically, they have difficulty adopting indirect teaching methods, making use of modern teaching means, as well as carrying out a detailed performance evaluation on students (Liakopoulou, 2011). However, this is not the case in this study where most of the teachers' were examiners who were knowledgeable on adapting economics content, method, activities, media and assessment to the ages of the learners. This study found that majority of form five students were within the ages of 14- 16 years and had studied economics for three year. This meant that, they were mentally, physically and socially ready to learn the formal, informal, hidden and tested curriculum of economics. From a cognitivist viewpoint, the findings were in congruent with Amalu and Dasel (2019) conclusion that secondary school students' academic achievements were enhanced by their internal locus of control and good study habits.

Furthermore, the findings of this study showed a positive effect of teachers' knowledge of adapting teaching methods and content on students' achievement in economics. These findings are similar to Darling-Hammond (2000) who argued that, effective teachers were able to adjust their teaching style to fit the needs and style of different learners because they had a wide repertoire of approaches and strategies, such as direct teaching, modelling interactive teaching strategies, cooperative learning techniques, and experienced-based and skill-based approaches.

Again, the findings showed that both teachers and students had massively accepted that oral test, followed by essay test, multiple choice test, structural test, problem solving test and graphic test were the most frequently used formative assessment practices that enhanced students learning in economics. From a constructivist standpoint, the findings were in congruent with Shulman's (1987) theory that meaningful learning occurred when teachers provided sensitive and constructive feedback to students and used assessment practices that encouraged selfassessment and metacognition. Thus, Shulman (1987) recommended that teachers must possess PCK along with knowledge of formative assessment and evaluation in order to accelerate students learning progress. Similarly, Falk (2012) found that teachers' PCK were a resource in all aspects of their formative assessment practice. This was because teachers constructed PCK through formative assessment by building and refining knowledge of curricular thus, enhancing students' achievement (Falk, 2012). In relation to this, Ballard and Bates (2008) indicated that ongoing assessment was effective for measuring students learning and teachers' effectiveness.

Results obtained showed that both students and teachers had proposed teachers' pedagogical content knowledge as a factor that enhanced form five students' examination scores in economics. To a larger extent, the respondents had indicated that teachers' knowledge of subject matter (such as presentation of content sequentially, applying concepts to real life situations and proper explanation of rationale of the topic to students) was the most prominent PCK component that enhanced students' achievement in economics, followed by the teachers' 
knowledge of formative assessment (such as giving students assignment, providing immediate and correct feedback to students and solving of past GCE questions with students), teachers' knowledge of teaching methods (such as proper use of appropriate teaching methods and encouraging students to buy and read textbooks) whereas teachers' knowledge of students' conception (such as motivating and counselling students regularly) was proposed as the least PCK component that enhanced students' achievement in economics. These findings were in agreement with those of Mishra and Koehler (2006) in which they expressed confidence in the positive effect of teachers' pedagogical content knowledge on students' achievement.

The findings were also in consonance with the findings of Luketero and Kangangi (2019), Kapur (2018), Olufemi, Adediran and Oyediran (2018) who maintained that: teachers factors (such as teachers' PCK, knowledge of students' conception (that is, motivating students regularly), knowledge of educational contexts); school factors (such as the availability of school resources and class size) and students factors (that is, the attitude of students, indecent dressing and poverty) were the fundamental factors that influenced students' achievement in schools. These findings were equally supported by Nkom, (2008); Schug, Dieterle, and Clark (2009); Wemnje, (2013); Akuro, (2015); Alobwede, (2015) as well as Kola and Sunday (2015) findings on teachers' knowledge which accentuated that the several key elements of PCK were the root behind successful instruction in core subject areas.

Teachers' professional development such as attending seminars and departmental meetings regularly was another crucial issue proposed that enhanced students' achievement in economics. In this regard, Howard, Hodgin and Zietz (2003) suggested that the kind of teachers' professional development used in schools has an effect on students' achievement. With this in mind, they argued that research activities may make teachers more active in their discipline and as a result more knowledgeable and interesting in the classroom.

Lastly, the findings showed that students' achievements at regional mock examinations were to a greater extent influenced by teachers' knowledge of formative assessment. This findings can be attributed to the fact that majority of the teachers immensely agreed that, they were participating in both the regional mock examination and GCE examination as opposed to the minority that disagreed that they were merely classroom teacher who only took part in the regional mock examinations. The findings have further shown a relationship between students' knowledge of regional mock examination via teachers' knowledge of formative assessment and their academic achievement at the GCE examinations. This statement corrobates a large majority of respondents in form five affirmations that, they had attended economics classes for three years or more and had participated in the regional mock examination(s) and/or GCE examination(s) once or repeatedly. The findings were in agreement with Black and William (1998) conclusion that, there is a positive effect of teachers' knowledge of formative assessment such as the regional mock examination on students' achievement.

\section{Conclusion and Recommendations}

To a larger extent, this study emphasized teachers' qualification, longevity, work status and PCK as salient demographic characteristics and knowledge to improve students' academic achievement in economics in secondary schools classes. To a lesser extent the study highlighted students' age and longevity of studying economics in form five as prominent demographic characteristics to enhance students' academic achievement in economics in secondary schools classes. From the on-going discussions, the study calls for a valuable pedagogic approach to help improve the quality of economics teachers and thereby help to improve students' academic achievement in Cameroonian schools. Valuable pedagogic approach may take many forms informed by many different teachers and students' demographic characteristics and teacher's PCK. What this implies is greater strengthening of the link between teaching and learning by adapting the organization and/or expansion of teacher training to include training on curriculum assessment for learning, tailoring pedagogies that are appropriate to students' development and developing students' global learning. Hence, seminars and conferences on PCK are highly recommended to be organized for teachers and teachers should have confidence in their ability to teach any topic within their specialized fields. Workshops and class meetings on learning skills are highly recommended to be organized for students and students should have confidence in their ability to understand concepts and learn any topic within the school curriculum. The study recommends that teachers' should be activity oriented in order to boost students' academic achievement.

\section{References}

Akuro, O. M. (2014). Sequential economics textbook for ordinary level. Bamenda, Cameroon: Destiny Prints.

Alobweb, E.E. (2015). Improving and sustaining academic standards: Poor performance in 525 economics/The way forward and the arts of constructing multiple-choice questions (MCQs). Buea: Shiloh Printers.

Amalu, M. N. and Dasel, N. J. (2019). Academic locus of control, study habits and secondary school students academic achievement in mathematics, International Journal of Research and Scientific Innovation (IJRSI), VI(XI) 19-23.

Amin, M.E. (2015). Social science research: Conception, methodology, and analysis. Kampala: Makerere University Printery. 
Arshad, M. and Akramnaseem, M. (2013). Comparison between the performance of trained and untrained teachers in Lahore, Global Journal of Human Social Science Linguistic and Education, 13(3) 86-96.

Ballard, K. and Bates, A. (2008). Making a connection between student achievement, teacher accountability, and quality classroom instruction, The Qualitative Report, 13(4), 560-580. http://nsuworks.nova.edu/tqr/wl.13/iss4/3

Black, P. and William, D. (1998). Assessment and classroom learning, Assessment in Education: Principles, Policy, and Practice, 5(1), 7-74. Doi:10.1080/0969595980050 102

Darling-Hammond, L. (2000). Teacher quality and student achievement: A review of state policy evidence, Education Policy Analysis Archives, 8(1), 1-44.

Falk, A. (2012). Teachers learning from professional development in elementary science: Reciprocal relations between formative assessment and pedagogical content knowledge, Journal of Science Education, 96, 265290.

Howard, H., Cochran, Jr., Hodgin, G. L. and Zietz, J. (2003). Student evaluations of teaching: Does pedagogy matter? , Journal for Economic Educators, 4(1), 6-18. https://www.researchgate.net/publication/228980215

Jepketer, A., Kombo, K. and Kyalo, D. N. (2015). Relationship between teacher capacity building strategy and students' performance in public secondary schools in Nandi county, Kenya, International Journal of Humanities and Social Science Invention, 4(10), 37-50.

Kapur, R. (2018). Factors influencing the students academic performance in secondary schools in India. Retrieved from https://www/reserchgate.net/publications/324819919.

Kiyong, S. Y. (2015). Practical teaching in economics for improved performance: Approach of presentation, Paper presented at economics seminar, P.C.H.S. Mankon, North West Region, Cameroon.

Kola, A. J. and Sunday, O. S. (2015). A review of teacher self-efficacy, pedagogical content knowledge (PCK) and out-of-field teaching: Focussing on Nigerian teachers, International Journal of Elementary Education, 4(3), 80-85. Doi:10.11648/j.ijeedu.20150403.15

Liakopoulou, M. (2011). The professional competence of teachers: Which qualities, attitudes, skills and knowledge contribute to a teacher's effectiveness? International Journal of Humanities and Social Science, 1(21), 6678.

Luketero, S. W. and Kangangi, E. W. (2019). Factors influencing students' academic performance in Kenya certificate of secondary education in Kirinyaga Central Sub Country, Kirinyaga Country Kenya, International Journal for Innovation Education and Research, 7(4), 1-11. Doi http://doi.org/10.31686/ijier.vol7.iss4.1143

Mishra, P. and Koehler, M. J. (2006). Technological pedagogical content knowledge: A framework for teacher knowledge. Teachers College Record, 108(6), 1017-1054. https://doi.org/10.1111/j.1467-9620.2006.00684.x

Munda, G. (2017). 2016/2017 Annual report from the Divisional Delegation of Secondary Education (DDSE), Report presented at the divisional conference, Divisional Delegation of secondary education Mezam, North West Region, Cameroon.

Nkom, E. N. (2008). The priniciples of modern economics: Adapted to the current GCE syllabus and MCQs. Douala, Cameroon: Leader Print.

NOWETA (2015). Practical teaching in economics for improved performance: Approach of presentation, Paper presented at NOWETA economics seminar, P.C.H.S. Mankon, North West Region, Cameroon.

Ntoh, T. E. (2015). Effective pedagogy for the social sciences under the new pedagogic approach: A pedagogic manual for teachers. Bamenda, Cameroon: Unique Printers.

Olufemi, O. T., Adediran, A. A. and Oyediran, W. O. (2018). Factors affecting students' academic performance in college of education in SouthWest, Nigeria, British Journal of Education, 6(10), 43-56.

Piaget, J. (1970). Piaget's theory. In P.H.Mussen (Ed.), Carmichael's manual of child psychology, $3^{\text {rd }}$ edition, 1 , 703-732. New York: John Wiley.

Schug, M.C., Dieterle, D.A. and Clark, J.R. (2009). Are high school economics teachers the same as other social studies teachers? The results of a national survey, Social Education, 73(2), 71-75.

Shulman, L. (1987). Knowledge and teaching: Foundations of the new reform, Harvard Educational Review, $57(1) 1-22$.

Tambo, L. I. (2003). Principles and Methods of Teaching. Buea: Anucam Publishers, 2003.

Walstad, W. B. and Watts, M. (2015). Perspectives on economics in the school curriculum: coursework, content, and research, Journal of Economic Education, 46(3), 324-39.

Wemnje, C. N. (2014). A new approach to ordinary level economics. Bamenda, Cameroon: Shilop Printers. 